\title{
HEAT TRANSFER MODELING AND VALIDATION IN THE CASE OF BUTT WELDED JOINTS
}

\author{
Gergely HALÁSZ ${ }^{1}$, János KUTI², Károly SZÉLL ${ }^{3}$ \\ 1,2, Óbuda University, Bánki Donát Faculty of Mechanical and Safety Engineering, Department of \\ Materials Technology, Budapest, Hungary \\ 1 gerryhalasz@gmail.com \\ ${ }^{2}$ kuti.janos@bgk.uni-obuda.hu \\ ${ }^{3}$ Óbuda University, Alba Regia Faculty, Institute of Engineering, 8000 Székesfehérvár, Hungary, \\ szell.karoly@amk.uni-obuda.hu
}

\begin{abstract}
The aim of our work is to compare the results of a virtual model to measure heat transfer data for butt welded joints. The primary goal is to compare real-time measured temperature with the software simulated data. The virtual model is a copy of the real product, technically a virtual prototyping process is examined. Prior to any production process such as joining by butt welding, real process parameters are tested on the model and later by experiments. In the case of many parts, the joining process is a key technology, where knowledge of the thermal effects of welding on the microstructure in the heat affected zone and the joint are vital.
\end{abstract}

Keywords: welding, heat affected zone, model validation.

\section{Heat transfer}

If two bodies and environments have different temperatures, heat transfer will occur, with the result that in time the temperature values will equalize. The heat transfer coefficient is the quantity of exchanged heat per unit of time and of the surface between the body and its environment, heat that travels in or out of the body perpendicular to the surface.

This heat exchange can be achieved with heat conduction, convective heat transfer and thermal radiation.

\subsection{Heat conduction}

During heat conduction, heat exchange occurs between adjacent resting parts, so it is typical for solid bodies. In liquids or gases, heat is spread when parts of the material are at rest. The thermal conductivity of the metals depends on the composition, structural state and temperature.

\section{Temperature measurement}

During the welding process, thermometers are needed to measure the temperatures; these are used to measure the temperature at certain points. Three temperature measurement methods were considered for the experiments, thermal imaging, thermocouple and infrared thermometers, of which the thermocouple is optimal.

\section{Preparation of experimental work- pieces}

The material of the specimen was S355, general purpose structural steel, in a cold-rolled state. The test pieces were provided by Messer Hungarogáz Kft. The size of the plates was $8 \times 100 \times 250 \mathrm{~mm}$. These test pieces were cut to size and grooved before welding in the laboratory. The grooved edge was $15^{\circ}$ for each piece and the preparation was $30^{\circ}$. Four holes were drilled in the prepared plate, $20 \mathrm{~mm}$ from the grooved edge, parallel to the weld line. Five $6 \mathrm{~mm}$ deep and $1.7 \mathrm{~mm}$ diameter bores were also drilled at $40 \mathrm{~mm}$ spacing. 
These holes ensure that the thermocouples provide the correct temperature values along the cross-section. The distance between holes was uniform for all pieces, $20 \mathrm{~mm}$ from the weld, 40 $\mathrm{mm}$ from the edge.

\section{Welding procedure}

Experimental welds were carried out at the University's Arc Welding Laboratory. For the sake of simplicity, the welds were made using a linear welding machine, whereby the welding speed was constant and errors from the welding staff were eliminated. The welding wire was electrically welded, with active shield-gas arc welding, known as MAG (Metal Active Gas) welding. The protective gas used was standard M21 gas (Ar + $18 \%$ CO2).

\subsection{The welding machine}

A linear welding machine was used to eliminate the welder error. Thanks to the unique machine designed by the students of the University, welding could be performed at a constant speed and wire feed. The work area of the machine is $1000 \times 660 \times 600 \mathrm{~mm}$. It was used to ensure that the speed, gun holding and welding current was equal to each measurement.

\section{Description of the experiment}

During the test welds, the welding current and the applicable welding voltage were determined by changing the speed of the wire feed. To create the appropriate weld, besides the welding current and voltage selected values, the welding speed was $14 \mathrm{~cm} / \mathrm{min}$. During the experiments, we worked with the following constant parameters: welding speed: $14 \mathrm{~cm} / \mathrm{min}$; current: $180 \mathrm{~A}$; Voltage: $23 \mathrm{~V}$.

The first test piece was placed on the workbench without support. The 5 thermo-couples were inserted in the holes and welded by the machine. During the welding, changes in current and temperature were observed. After finishing the welding, we documented the finished weld and waited until the specimen cooled down to $100^{\circ} \mathrm{C}$. Then we removed the thermocouples, labelled the piece and documented the root side. The second specimen was supported by a thin wire at both ends to minimize heat losses. A small heat loss resulting from the support also appears in the temperature of the thermocouple. At the end of the welding, the root side was documented.
After the second test, we did not change the initial conditions, all condition remained the same during the third and fourth welding experiments.

\section{Presentation of the model}

With the basic data obtained, in the MSC Marc Mentat finite element program, we prepared the welded cross-section, with approximate size and shape. We examined the heat transfer in the cross-section, so my model shows the weld in two dimensions. With consideration of the edge grooving, near the weld the points, a fine mesh was built to obtain the most accurate measurement results.

In the $4^{\text {th }}$ experiment, we were able to filter all the problems, and the welding machine was operating at the best possible setting for its size, therefore we used this specimen for preparation of the finite element geometry.

The width of the model was less than the size of the specimen. To overcome this problem, we set heat withdrawals on both sides, representing the heat withdraw of other materials. Then we set the welding parameters, specifying welding properties, flux, material properties, initial and boundary conditions.

\subsection{Material properties}

The thermal material properties in the simulations were:

- specific heat: $576 \mathrm{~J} / \mathrm{kg}^{\circ} \mathrm{C}$,

- density: $7850 \mathrm{~kg} / \mathrm{dm}^{3}$,

- thermal conductivity: $0.04 \mathrm{~W} / \mathrm{mm}^{\circ} \mathrm{C}$.

\subsection{Boundary conditions}

To set the thermal boundary condition, we recorded a point flux. Because the electric arc between the electrode and the workpiece was closed at a certain point, that's where the maximum temperature was.

\subsection{Initial conditions}

The temperature of the base material was the same as the ambient temperature before the welding started.

\subsection{Load cases}

The temporal length of the entire process was determined here. Since the heat transfer was examined in the perpendicular section of the weld, the heat flux applied to the test piece should only be operated for a short time. However, the heat spread must be observed during the entire welding process because it takes more time for the heat dissipation to take place. 
Once the conditions had been set, we ran the simulation. The three specified sections are clearly distinct when running the model. In the first stage, when the arc just passes, the melt temperature is still above the melting point.

In the second stage, the heat spreads throughout the piece. The weld and its surroundings are still at different temperatures. The temperature in the heat-effect zone is also high.

In the third stage - which is the longest stage, so it takes more time to take up the points - the heat loss is visible. The specimen will slowly cool down. Still relatively warm in the vicinity of the weld, it approaches room temperature further away from the weld.

\section{Results, Summary}

For comparison of the measured and calculated results, we used the data of all 4 measurements and evaluated the results of 4 measuring points. We have included these data in diagrams to make them more transparent. From these, only one of them is shown here. Compared with the results in the model, the direction of the curves shows many similarities, but the maximum temperature slightly deviates. Based on the data it can be stated that the model fits relatively well the results of real welding, but there is still room for improvements.

The deviation between the maximum and the cooling point is about $50^{\circ} \mathrm{C}$. This is probably due to the fact that the heat dissipation values given in the model are smaller than the real ones.

Because of the dimensions we had to estimate the values of heat loss, in the next simulation, this value can be corrected based on the measured results, which is likely to bring the simulation values closer to reality. Additionally, software settings are to be optimized further. Due to time constraints, it is possible that the deviation is due to the parameters defined during modeling and errors of the geometry.

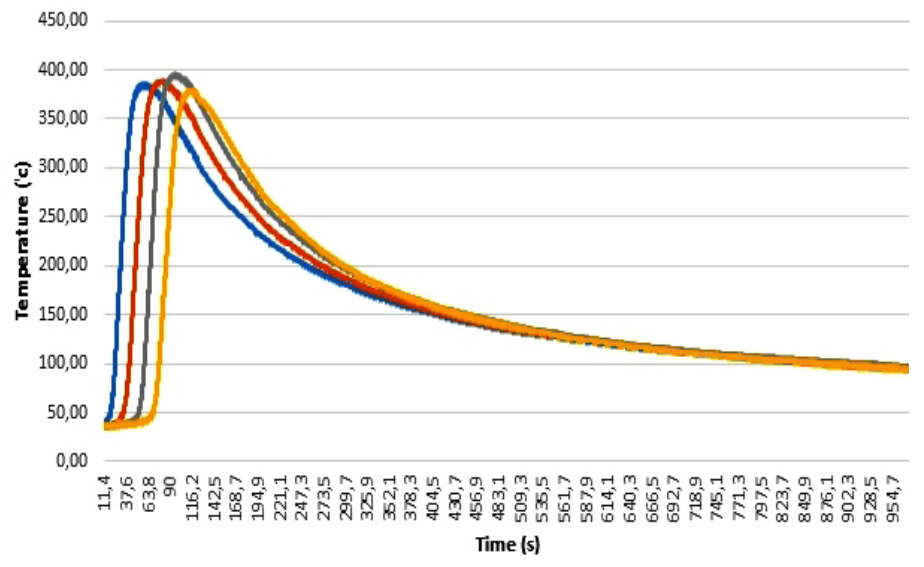

Figure 1. Temperature values measured with thermocouples

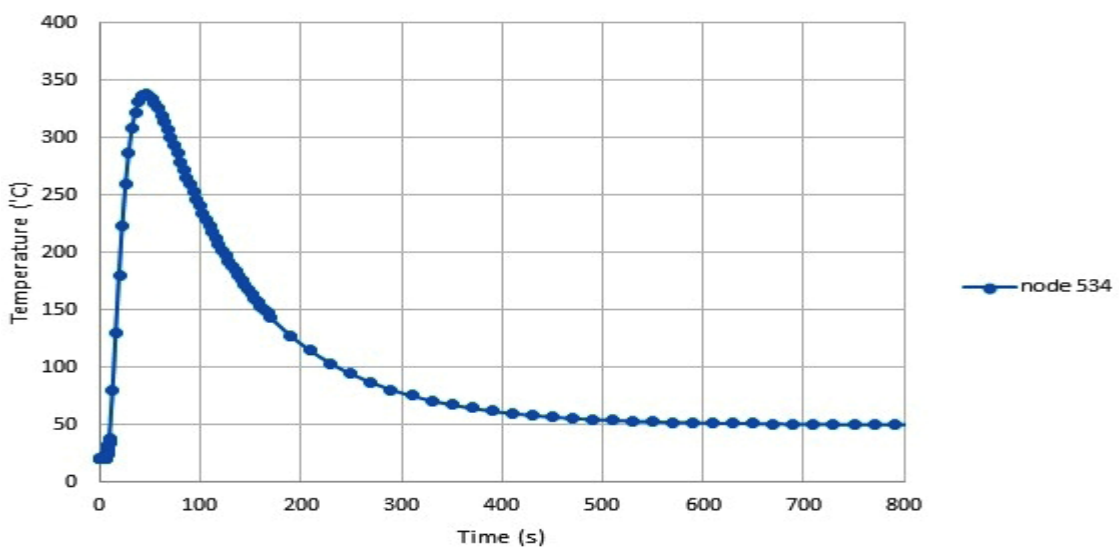

Figure 2. Temperature values derived from the finite element simulation 


\section{Acknowledgements}

The authors hereby wish to thank for the financial support given to our work - to the EFOP-3.6.1-162016-00010 project - the Hungarian state and the European Union.

\section{References}

[1] Komócsin M.: Gépipari anyagismeret. Okom Mérnökiroda Kft., Miskolc, 1997.

[2] Szombatfalvy Á.: A hőkezelés technológiája. Műszaki Könyvkiadó, Budapest, 1985, 9-12.
[3] Hütte: A mérnöki tudományok kézikönyve. Budapest; Berlin; Heidelberg; New York; London; Paris; Tokyo; Hong Kong; Barcelona, Springer-Verlag, 1993.

[4] Horváth K., Simonyi A., Zobory I.: Mérnöki fizika. Müegyetemi Kiadó, Budapest, 1992.

[5] Gremsperger G., Marti S., Rejtő F.: Ívhegesztő áramforrások. Müszaki könyvkiadó, Budapest, 1987.

[6] Marc ${ }^{\circledR} 2013$ Volume A: Theory and User Information, MSC Software Corporation, 2013, 270. 